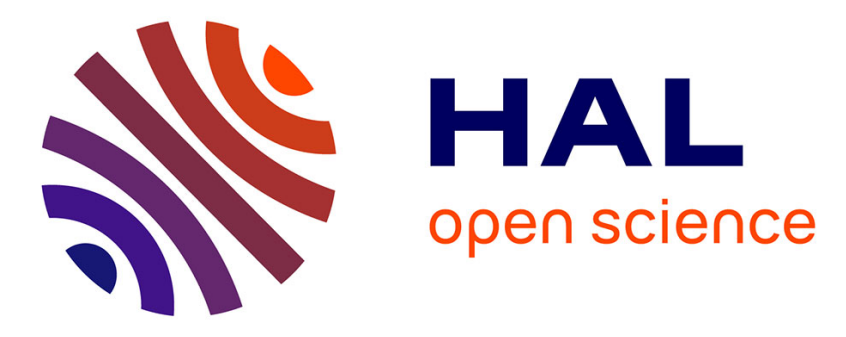

\title{
Role of V-pits in the performance improvement of InGaN solar cells
}

\author{
Muhammad Arif, Jean-Paul Salvestrini, Jérémy Streque, Matthew B. Jordan, \\ Youssef El Gmili, Suresh Sundaram, Xin Li, Gilles Patriarche, Paul L. Voss, \\ Abdallah Ougazzaden
}

\section{To cite this version:}

Muhammad Arif, Jean-Paul Salvestrini, Jérémy Streque, Matthew B. Jordan, Youssef El Gmili, et al.. Role of V-pits in the performance improvement of InGaN solar cells. Applied Physics Letters, 2016, 109 (13), pp.133507. 10.1063/1.4963817 . hal-02385085

\section{HAL Id: hal-02385085 https://hal.science/hal-02385085}

Submitted on 24 Feb 2022

HAL is a multi-disciplinary open access archive for the deposit and dissemination of scientific research documents, whether they are published or not. The documents may come from teaching and research institutions in France or abroad, or from public or private research centers.
L'archive ouverte pluridisciplinaire HAL, est destinée au dépôt et à la diffusion de documents scientifiques de niveau recherche, publiés ou non, émanant des établissements d'enseignement et de recherche français ou étrangers, des laboratoires publics ou privés.

\section{(ㅇ)(1) $\$$}

Distributed under a Creative Commons Attribution - NonCommercial| 4.0 International 


\title{
Role of V-pits in the performance improvement of InGaN solar cells
}

\author{
Muhammad Arif, ${ }^{1,2}$ Jean-Paul Salvestrini, ${ }^{1,2, a)}$ Jérémy Streque, ${ }^{1}$ Matthew B. Jordan, ${ }^{1,3}$ \\ Youssef El Gmili, ${ }^{1}$ Suresh Sundaram, ${ }^{1}$ Xin Li, ${ }^{1}$ Gilles Patriarche, ${ }^{4}$ Paul L. Voss, ${ }^{1,3}$ \\ and Abdallah Ougazzaden ${ }^{1,3}$ \\ ${ }^{1}$ Georgia Tech Lorraine and CNRS, UMI2958, 57070 Metz, France \\ ${ }^{2}$ Université de Lorraine and CentraleSupélec, LMOPS EA4423, 57070 Metz, France \\ ${ }^{3}$ School of Electrical and Computer Engineering, Georgia Institute of Technology, Atlanta, \\ Georgia 30332-0250, USA \\ ${ }^{4}$ CNRS, UPR LPN, 91460 Marcoussis, France
}

(Received 6 June 2016; accepted 18 September 2016; published online 29 September 2016)

\begin{abstract}
We study the influence of V-pits on the overall conversion efficiency of bulk $\operatorname{In}_{0.12} \mathrm{Ga}_{0.88} \mathrm{~N}$ based heterojunction solar cells grown by MOVPE. We show that V-pits significantly enhances the extraction of the photogenerated carriers in the InGaN absorber, resulting in a peak external quantum efficiency of $79 \%$ and a short circuit current density (twice the state of the art) of $2.56 \mathrm{~mA} / \mathrm{cm}^{-2}$ under AM 1.5G conditions. Published by AIP Publishing. [http://dx.doi.org/10.1063/1.4963817]
\end{abstract}

The InGaN material system, with its bandgap spanning the entire visible solar spectrum, enables the design of multijunction solar cells of maximum efficiency. The high energy radiation resistance and absorption coefficient make InGaN a potential candidate for high efficiency photovoltaic (PV) devices. ${ }^{1}$ Nevertheless, there are two major challenges ${ }^{2,3}$ that could limit the realization of high efficiency $\mathrm{InGaN}$ solar cells. New approaches ${ }^{4}$ have been proposed to overcome the first of these challenges, which deals with the growth of a high structural quality thick InGaN absorber layer with high indium (In) concentration. Two methods to prevent phase separation and high dislocation density in the absorber are the substitution of the bulk absorber by either a semibulk absorber $^{5,6}$ or InGaN nano-structures. ${ }^{7}$ We have shown encouraging results. ${ }^{8}$ The nanostructures allow full strain relaxation of the InGaN material without any threading dislocations (TDs), high In incorporation, ${ }^{9}$ and growth on silicon template. ${ }^{10}$ The second challenge is the degradation of the structural properties of the InGaN absorber during the growth of the subsequent top p-GaN layer. The latter is generally grown at a temperature, which is much higher than what the InGaN layer can withstand. To prevent that, the $\mathrm{p}-\mathrm{GaN}$ layer is grown at a lower temperature, which leads to a rather low crystal quality with a high density of TDs and V-pits, resulting in high carrier recombinations and leakage current leading to InGaN solar cells with reduced open circuit voltage $\left(V_{o c}\right)$ as reported by several authors. ${ }^{11-13}$ These authors also reported increased values of the short circuit current density $J_{s c}$ for devices exhibiting the largest density of V-pits. This was explained by a possible reduction of the light reflection at the $\mathrm{p}-\mathrm{GaN}$ surface leading to an increase in the light absorption and thus $J_{s c}$.

We propose another possible explanation for this enhancement of $J_{s c}$ originating from the presence of V-pits in the $\mathrm{p}-\mathrm{GaN}$ layer. Because V-pits exhibit enhanced carrier collection in the surrounding area as shown by Frigeri ${ }^{14}$ and Maximenko et al., ${ }^{15}$ a large density of V-pits could thus lead to the enhancement of $J_{s c}$. To assess this assumption, a more

${ }^{a)}$ Electronic mail: jean-paul.salvestrini@univ-lorraine.fr comprehensive study is required. That is the purpose of this paper. We use the electron beam induced current (EBIC) technique which, with its high spatial resolution down to the sub-micron level, allows accurate characterization of the generated current within and around the V-pits. Correlation of EBIC results with device characteristics allows the full interpretation of the role of these defects in the performance of the PV cells.

To demonstrate this, as shown in Fig. 1(a), a PIN structure is grown using MOVPE on a GaN template. It consists of an $850 \mathrm{~nm}$ thick Si-doped n-type GaN layer followed by a $50 \mathrm{~nm}$ thick non intentionally (NID) doped GaN layer (to stop the diffusion of $\mathrm{Si}$ from the $\mathrm{n}-\mathrm{GaN}$ layer into the intrinsic region). Then, a $60 \mathrm{~nm}$ thick NID $\operatorname{In}_{0.12} \mathrm{Ga}_{0.88} \mathrm{~N}$ layer is grown to form the active region. A $10 \mathrm{~nm}$ NID GaN cap layer (to stop the diffusion of $\mathrm{Mg}$ from the $\mathrm{p}-\mathrm{GaN}$ layer into the intrinsic region) followed by a $200 \mathrm{~nm}$ thick $\mathrm{Mg}$ doped p-type $\mathrm{GaN}$ and a $50 \mathrm{~nm}$ of heavily $\mathrm{Mg}$ doped $\mathrm{p}^{+}$-type $\mathrm{GaN}$ were grown at $800^{\circ} \mathrm{C}$. The processing of the devices, with size ranging from $0.37 \mathrm{~mm}^{2}$ to $1.27 \mathrm{~mm}^{2}$, includes the realization of both n- and p-contacts (see Fig. 1(b)). For the p-contact, a top grid with $5 \mu \mathrm{m}$ wide fingers and a pitch of $75 \mu \mathrm{m}$ is formed using $\mathrm{Pd} / \mathrm{Au}$ metal layers for the p-contact.

(a)

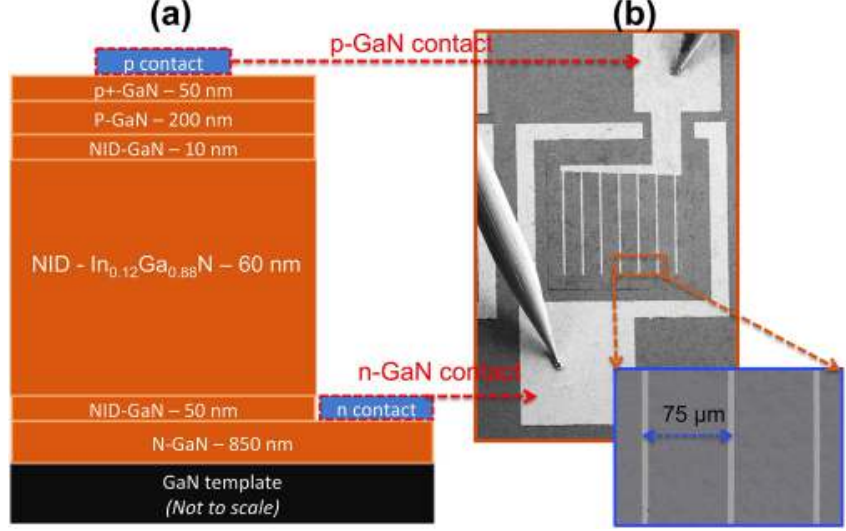

FIG. 1. (a) Design and (b) SEM image of the InGaN PV structure. 

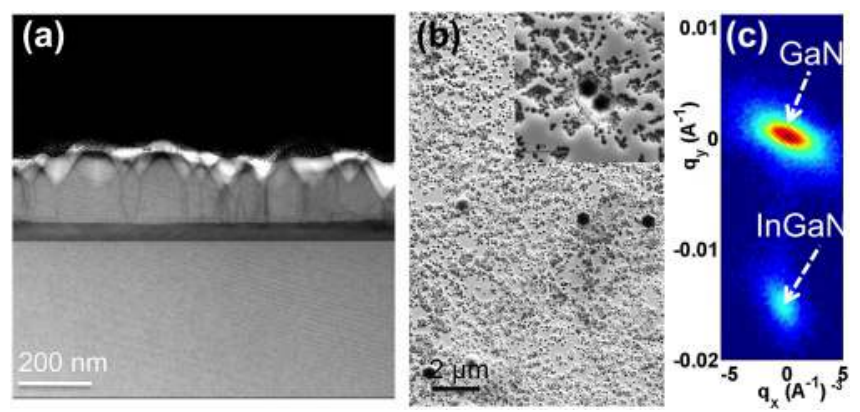

FIG. 2. (a) HAADF-STEM cross-sectional and (b) SEM images (c) (11-24) RSM of the InGaN PV structures.

The n-contact is formed using Ti/Al/Au metal layers. Details of the processing are described in the work of Belahsene et al. ${ }^{16}$

The growth of the $\mathrm{p}-\mathrm{GaN}$ layer at low temperature $\left(800^{\circ} \mathrm{C}\right)$ leads to a well preserved InGaN absorber layer, with the exception of some small V-pits in the upper part of the layer, as well as a relatively abrupt and smooth interface with few defects between the InGaN absorber and the p-GaN layer. This is shown in the high-angle, annular dark field scanning transmission electron microscopy (HAADF-STEM) image in Fig. 2(a). A high density of V-pits is observed in the p-GaN layer as seen in Fig. 2(b), which shows the SEM image of the $\mathrm{p}$-GaN surface. The width of the opening of these $\mathrm{V}$-pits varies from $30 \mathrm{~nm}$ to $1000 \mathrm{~nm}$. X-ray diffraction reciprocal space mapping, shown in Fig. 2(c), indicates that the InGaN layer, with an average In content of $12 \%$, is mostly coherently strained ( $8 \%$ of relaxation) to the GaN template. Energy dispersive X-ray spectrometry (EDX) measurements (not shown here) confirm an average In concentration in the InGaN layer of $12 \%$. A high resolution $2 \theta-\omega$ scan of the full PIN structure (not shown here) shows clearly resolved Pendellosung fringes on both sides of the main InGaN peak (with 368 arc sec FWHM for (0002) planes), which confirms the high structural quality of the InGaN layer and the well-defined interface between $\mathrm{InGaN}$ and $\mathrm{GaN}$ layers (with 337 arc sec FWHM for (0002) planes, close to that of the $\mathrm{GaN}$ template).
To investigate the role of the V-pits in the performance of the InGaN-based solar cells, we carried out an in-depth EBIC analysis of 6 selected devices with different V-pit densities. EBIC measurements were done using electrical contacts prepared for the electro-optical characterization of the PV cells. To measure the induced current, two probes connected to a current-voltage amplifier were placed on the $n$ and p pads, respectively, as shown in Fig. 1(b). The generated electrons are collected by the highly doped n-GaN layer via the $\mathrm{n}$-pad, whereas the generated holes are collected via interdigitated electrodes deposited on the $\mathrm{p}$-GaN layer and connected to the p-pad. As an example, Fig. 3 shows the SEM and corresponding EBIC images, respectively, recorded at different scales, in a planar geometry configuration for one of the InGaN PV cells and obtained for an electron beam energy of $13 \mathrm{keV}$. The large scale EBIC mapping shown in Fig. 3(b) exhibits a dark area corresponding to the metal contacts that avoid any carrier generation due to the full absorption of the electron beam. Also an inhomogeneous bright area can be seen, indicating an inhomogeneous carrier collection through the full device. At higher magnification (Figs. 3(c)-3(f)), it is clear that the non homogeneous carrier collection matches perfectly with V-pit spatial distribution and size in the p-GaN layer. As shown in Fig. 4, smooth areas without any pits (SA) are less bright than areas containing small and thus shallow V-pits (SVP), which are, in turn, darker than areas containing large and thus deep V-pits (DVP). This could be explained by the fact that the arrangement of core atoms in TDs differs considerably from the position in the bulk-like material and thus gives rise to a strain field, which could act as a trap for intrinsic defects and impurities. ${ }^{17}$ This impurity trapping would inhibit the overgrowth leading to the opening of the TDs, resulting in nanotubes or open-core defects and then V-pits. Therefore, an impurity-depleted zone would be expected to form around the V-pits. ${ }^{15}$ During the growth of GaN type materials, impurities such as silicon $(\mathrm{Si})$, oxygen $(\mathrm{O})$, and hydrogen $(\mathrm{H})$ can be incorporated. $\mathrm{Si}$ and $\mathrm{O}$ are donors and with $\mathrm{H}$ can form a complex with $\mathrm{Mg}$, leading to the reduction
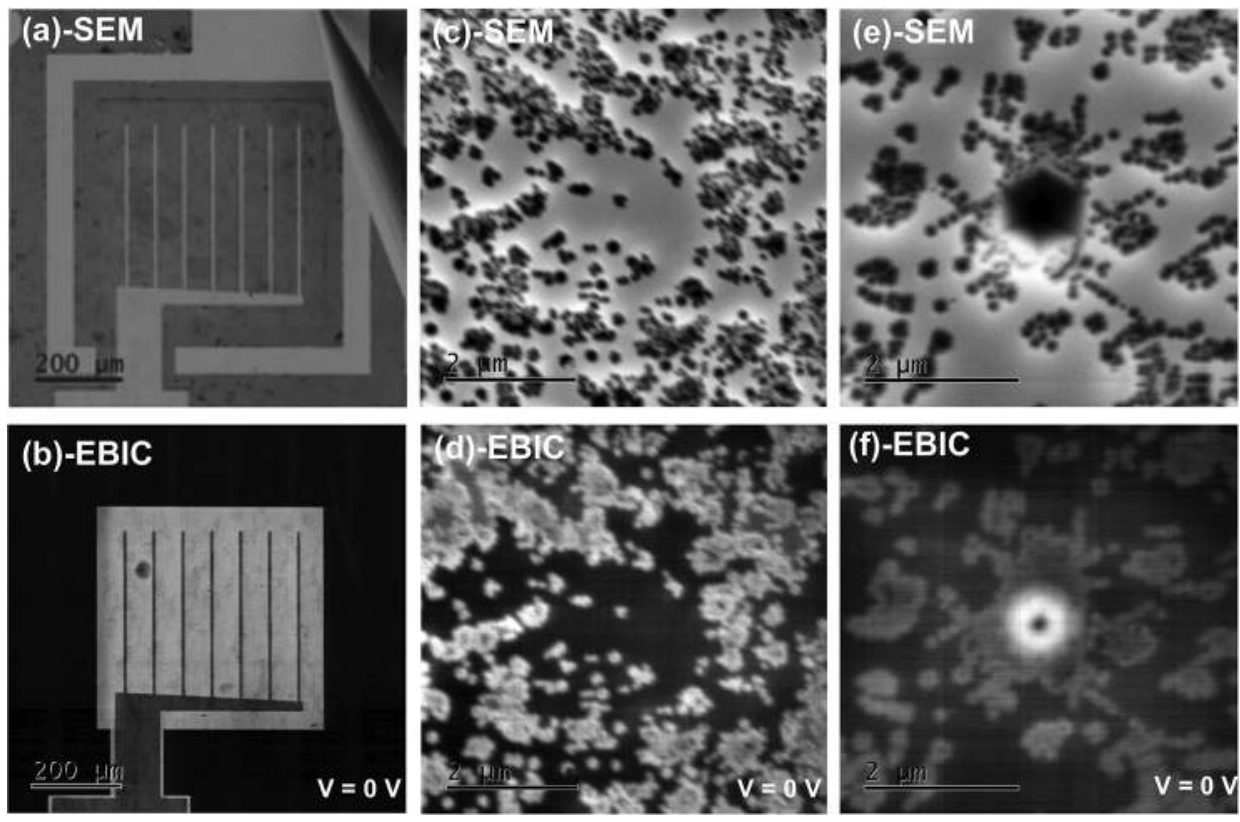

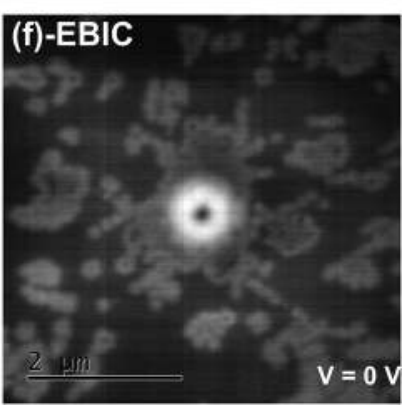

FIG. 3. Different magnification of (a), (c), and (e) SEM images of the $\mathrm{H}_{1}$ InGaN device top surface, and (b), (d), and (f) corresponding EBIC images. 


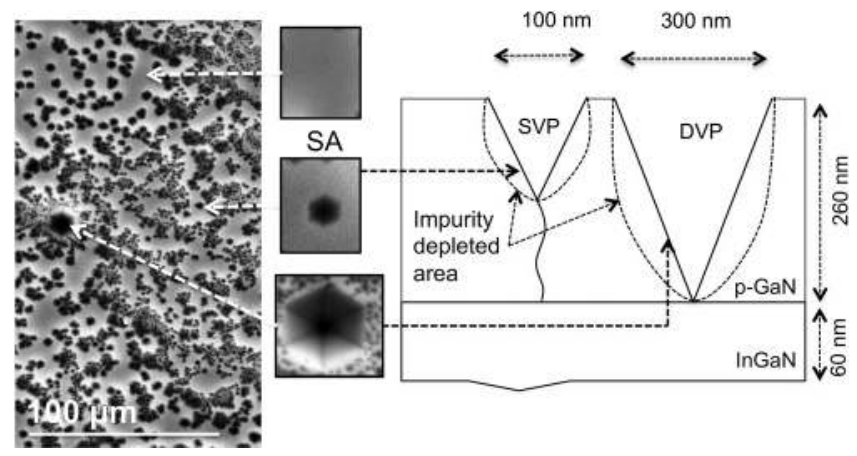

FIG. 4. (a) and (b) SEM images and profiles of both DVP and SVP of the device top surface and (c) and (d) their corresponding EBIC images and profiles obtained at an e-beam energy of $13 \mathrm{keV}$.

of the p-doping concentration, which eventually results in low carrier collection efficiency and thus EBIC signal. The impurity-depleted zone around the V-pits is thus expected to show an enhanced EBIC signal. The difference in the brightness of DVP and SVP in the EBIC images can be then attributed to the difference in the impurity depleted volume. It is to be noticed that the center of the DVP appears dark (see Figs. 3(f), 5(a), and 5(b)) likely due the absence of p-GaN on top of the InGaN layer at this particular location (see Fig. 4).

The EBIC images recorded at different scales in all of the six devices have been accurately analyzed. For each device, the DVP (size larger than $300 \mathrm{~nm}$ ) and SVP (size lower than $300 \mathrm{~nm}$ ) densities have been carefully determined using a Matlab code and correlated with the corresponding device performance $\left(J_{s c}\right.$ and $V_{o c}$ measured under UV illumination). Depending on the deep and shallow V-pit density ratio in the $\mathrm{p}$-GaN layer over the full wafer surface, large variations of the performance from one device to another are observed. As soon as the total pit density is decreased from one device to another, a decrease in $J_{s c}$ and an increase in $V_{o c}$ are observed. Figure 6 shows the dependence of both $J_{s c}$ and $V_{o c}$ with DVP and SVP densities, respectively. There is a strong correlation between the DVP density and $V_{o c}$

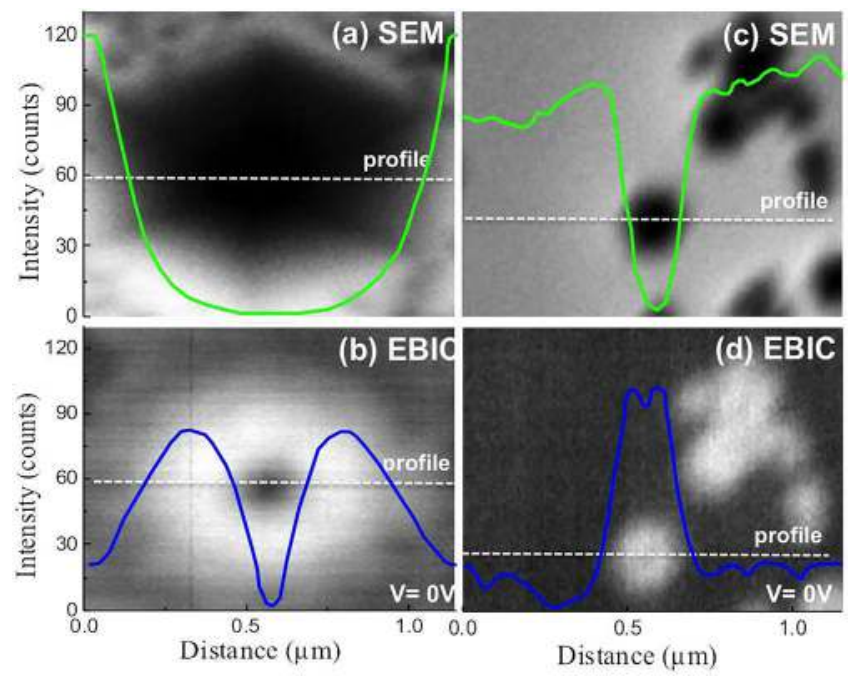

FIG. 5. Scheme of the deep and shallow V-pits observed in the p-GaN layer of the PV devices. V-pits with opening larger than $300 \mathrm{~nm}$ extend down to the InGaN layer.

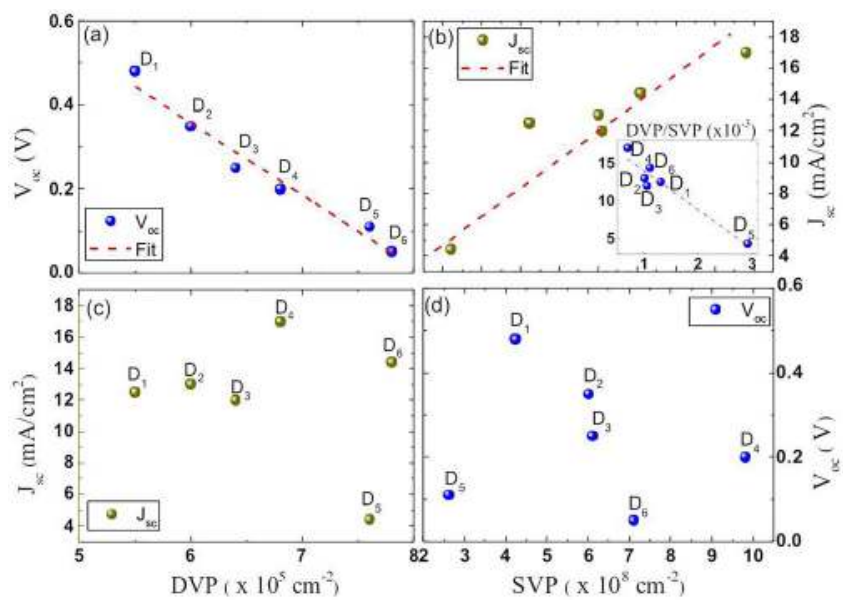

FIG. 6. $J_{s c}$ and $V_{o c}$ dependence with the DVP and SVP densities, respectively. Measurements were done under UV light and recorded in 6 different devices labeled $\mathrm{D}_{1}-\mathrm{D}_{6}$.

(Fig. 6(a)). A good correlation is also observed between SVP density and $J_{s c}$ (Fig. 6(b)). This correlation can be enhanced by plotting $J_{s c}$ versus the DVP/SVP density ratio as shown in the inset of Fig. 6(b). On the contrary, a weak or zero correlation exists between DVP density and $J_{s c}$ (Fig. 6(c)), likely due to the fact that the DVP density is $10^{3}$ times less than the SVP density. Finally, no correlation between SVP and $V_{o c}$ (Fig. 6(d)) can be seen. It can be seen that to increase both $J_{s c}$ and $V_{o c}$, an increase in the SVP density and a decrease in the DVP density are required, while to decrease both $J_{s c}$ and $V_{o c}$, a decrease in the SVP density and an increase in the DVP density are required. Finally, an increase in the SVP density leads to an increase in $J_{s c}$, whereas an increase in the DVP density leads to a decrease in $V_{o c}$. Thus, the rather low $V_{o c}$ observed in all the six devices can be attributed to some current leakage occurring at the DVP/InGaN layer interface and through the internal DVP surface, while the large current density observed in most of the devices could originate from the total impurity depleted volume, and corresponding electric field enhancement, due to DVP and SVP.

To go further and compare the performances of the devices with the literature, external quantum efficiency (EQE) and current density - voltage $(J-V)$ (under AM 1.5G conditions) measurements were performed. Figure 7 shows the results obtained for the device having the best performance $\left(D_{1}\right)$. The EQE curve has a maximum peak of $79 \%$ at a wavelength of $387 \mathrm{~nm}$ (see Fig. 7(a)). For wavelength greater than $387 \mathrm{~nm}$, a sharp decrease is observed down to a wavelength of $440 \mathrm{~nm}$ as expected and is followed by a second smooth decrease down to a wavelength of $505 \mathrm{~nm}$. The latter probably originates from higher In concentration regions in the partially relaxed InGaN layer. The decrease in EQE below $365 \mathrm{~nm}$ is due to photon absorption and charge generation in the p-GaN layer that cannot be collected. From Fig. 7(b), which shows the $J-V$ dependence measured under AM $1.5 \mathrm{G}$ conditions, a value of $2.56 \mathrm{~mA} / \mathrm{cm}^{2}$ for $J_{s c}$ can be determined, which is the maximum value ever reported for a PIN heterojunction solar cell, with a $60 \mathrm{~nm}$ thick $\operatorname{In}_{0.12} \mathrm{Ga}_{0.88} \mathrm{~N}$ absorber layer. Table I summarizes and compares the performances of the best InGaN solar cells with those reported by Matioli et al. ${ }^{13}$ who achieved the best $60 \mathrm{~nm}$ thick 

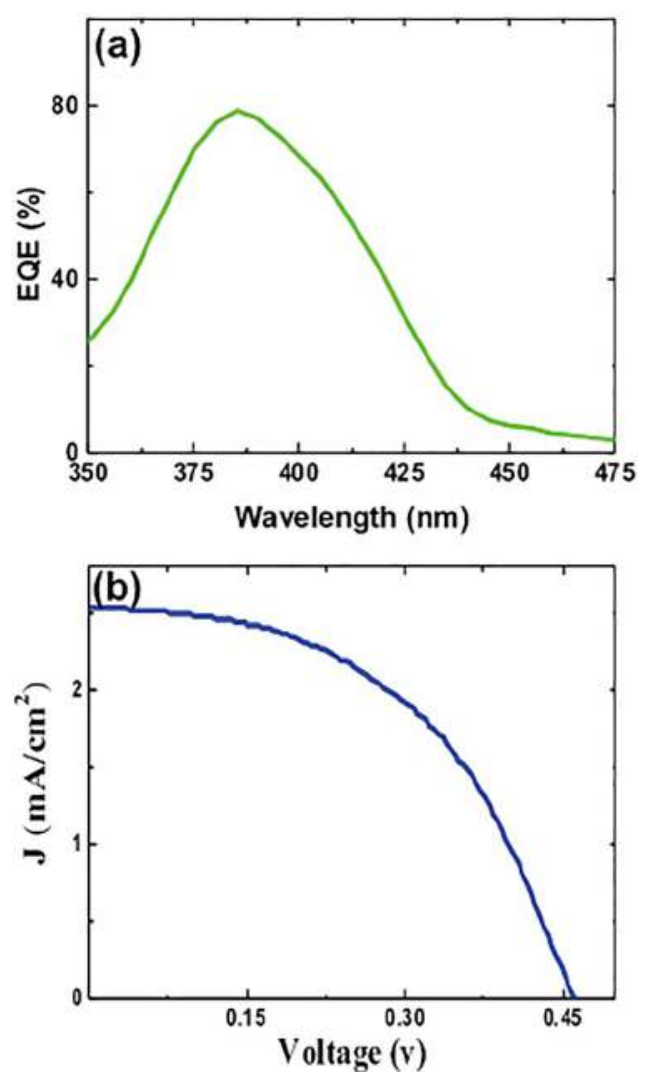

FIG. 7. (a) EQE spectrum and (b) corresponding $J-V$ dependence measured under the AM $1.5 \mathrm{G}$ solar spectrum.

TABLE I. Comparison of the performance of the $60 \mathrm{~nm}$ thick $\operatorname{In}_{0.12} \mathrm{Ga}_{0.88} \mathrm{~N}$ absorber based PV cell with the literature. PCE is the power conversion efficiency.

\begin{tabular}{lccccc}
\hline \hline & $V_{o c}(\mathrm{~V})$ & $J_{s c}\left(\mathrm{~mA} / \mathrm{cm}^{2}\right)$ & $\mathrm{FF}(\%)$ & PCE (\%) & Peak EQE (\%) \\
\hline This work & 0.48 & 2.56 & 40 & 0.49 & 79 \\
Literature $^{13}$ & 1.89 & 1.06 & 78.6 & 1.57 & 72 \\
\hline \hline
\end{tabular}

$\mathrm{In}_{0.12} \mathrm{Ga}_{0.88} \mathrm{~N}$ PV cells. We obtain larger $J_{s c}$ and EQE, thanks to SVP, but lower $V_{o c}$ and FF, both likely due to DVP.

In conclusion, we have studied the combining results of SEM, HAADF-STEM, current density voltage curves, and EBIC characterization, and the influence of the V-pits on the overall conversion efficiency of bulk $\operatorname{In}_{0.12} \mathrm{Ga}_{0.88} \mathrm{~N}$ absorber based heterojunction solar cells. We have shown that V-pits contribute significantly to the enhancement of photogenerated carrier extraction from the InGaN absorber, resulting in a peak external quantum efficiency of $79 \%$ and a short circuit current density of $2.56 \mathrm{~mA} / \mathrm{cm}^{-2}$ under an AM $1.5 \mathrm{G}$ solar spectrum, i.e., a value twice the state of the art. Meanwhile, a too high density of deep V-pits leads to high leakage current, hence reducing both the open circuit voltage and fill factor. Because a low growth temperature for the p-GaN layer, leading to high V-pit density, is mandatory, a way to favor the formation of shallow against deep V-pits should help to preserve and perhaps improve InGaN based $\mathrm{PV}$ device performances.

The author would like to thank Dr. A. Ramdane and S. Belahsene for device processing at LPN CNRS, Marcoussis, France. This study has been funded by the French National Research Agency (ANR) under the NOVAGAINS (ANR12-PRGE-0014-02) ANR Project and GANEX Program (ANR-11-LABX-0014).

${ }^{1}$ J. Wu, W. Walukiewicz, K. Yu, W. Shan, J. Ager Iii, E. Haller, H. Lu, W. J. Schaff, W. Metzger, and S. Kurtz, J. Appl. Phys. 94(10), 6477-6482 (2003).

${ }^{2}$ G. Orsal, Y. El Gmili, N. Fressengeas, J. Streque, R. Djerboub, T. Moudakir, S. Sundaram, A. Ougazzaden, and J. Salvestrini, Opt. Mater. Express 4(5), 1030-1041 (2014).

${ }^{3}$ L. Liang, Z. De-Gang, J. De-Sheng, L. Zong-Shun, C. Ping, W. LiangLiang, L. Ling-Cong, W. Hui, and Y. Hui, Chin. Phys. Lett. 30(2), 028801 (2013).

${ }^{4}$ M. Arif, S. Sundaram, J. Streque, Y. El Gmili, R. Puybaret, S. Belahsene, A. Ramdane, A. Martinez, G. Patriarche, T. Fix, A. Slaoui, P. L. Voss, J.P. Salvestrini, and A. Ougazzaden, $C P V-11$ (AIP Publishing, 2015), Vol. 1679 , p. 040001.

${ }^{5}$ Y. El Gmili, G. Orsal, K. Pantzas, T. Moudakir, S. Sundaram, G. Patriarche, J. Hester, A. Ahaitouf, J. Salvestrini, and A. Ougazzaden, Acta Mater. 61(17), 6587-6596 (2013).

${ }^{6}$ D. Van Den Broeck, D. Bharrat, Z. Liu, N. A. El-Masry, and S. Bedair, J. Electr. Mater. 44(11), 4161-4166 (2015).

${ }^{7}$ S. Sundaram, R. Puybaret, Y. El Gmili, X. Li, P. Bonanno, K. Pantzas, G. Orsal, D. Troadec, Z.-H. Cai, G. Patriarche, P. L. Voss, J.-P. Salvestrini, and A. Ougazzaden, J. Appl. Phys. 116(16), 163105 (2014).

${ }^{8}$ M. Arif, W. Elhuni, J. Streque, S. Sundaram, S. Belahsene, Y. E. Gmili, M. Jordan, X. Li, G. Patriarche, A. Slaoui, A. Migan, R. Abderrahim, Z. Djebbour, P. L. Voss, J.-P. Salvestrini, and A. Ougazzaden, "Improving InGaN heterojunction solar cells efficiency using a semi bulk absorber," Sol. Energy Mater. Sol. Cells (to be published).

${ }^{9}$ S. Sundaram, R. Puybaret, X. Li, Y. El Gmili, J. Streque, K. Panztas, G. Orsal, G. Patriarche, P. L. Voss, J.-P. Salvestrini, and A. Ougazzaden, Phys. Status Solidi A 212(4), 740-744 (2015).

${ }^{10}$ S. Sundaram, Y. El Gmili, R. Puybaret, X. Li, P. Bonanno, K. Pantzas, G. Patriarche, P. L. Voss, J.-P. Salvestrini, and A. Ougazzaden, Appl. Phys. Lett. 107(11), 113105 (2015).

${ }^{11}$ C. J. Neufeld, Z. Chen, S. C. Cruz, N. G. Toledo, S. P. DenBaars, and U. K. Mishra, in 35th IEEE PVSC (IEEE, 2010), pp. 002089-002092.

${ }^{12}$ R. M. Farrell, A. A. Al-Heji, C. J. Neufeld, X. Chen, M. Iza, S. C. Cruz, S. Keller, S. Nakamura, S. P. DenBaars, U. K. Mishra, and J. S. Speck, Appl. Phys. Lett. 103(24), 241104 (2013).

${ }^{13}$ E. Matioli, C. Neufeld, M. Iza, S. C. Cruz, A. A. Al-Heji, X. Chen, R. M. Farrell, S. Keller, S. DenBaars, U. Mishra, S. Nakamura, J. Speck, and C. Weisbuch, Appl. Phys. Lett. 98(2), 021102 (2011).

${ }^{14}$ C. Frigeri, Mater. Sci. Eng. B 20(1), 175-179 (1993).

${ }^{15}$ S. Maximenko, S. Soloviev, D. Cherednichenko, and T. Sudarshan, Appl. Phys. Lett. 84, 1576 (2004).

${ }^{16}$ S. Belahsene, G. Patriarche, D. Troadec, S. Sundaram, A. Ougazzaden, A. Martinez, and A. Ramdane, J. Vac. Sci. Technol., B 33(1), 010603 (2015).

${ }^{17}$ M. Haugk, J. Elsner, T. H. Frauenheim, T. E. M. Staab, C. D. Latham, R. Jones, H. S. Leipner, T. Heine, G. Seifert, and M. Sternberg, Phys. Status Solidi B 217(473), 473-511 (2000). 